\title{
ДІАГНОСТИКА ОСОБЛИВОСТЕЙ РЕАДАПТАЦІЇ ПЕДАГОГІВ ПРЕДПЕНСІЙНОГО ВІКУ В УМОВАХ СОЦІАЛЬНО-ОСВІТНІХ उMIH
}

Удк: 159.99

\section{Вальо Лариса Іванівна}

\begin{abstract}
Кандидат кандидат психологічних наук, викладач психології Свалявського технічного коледжу Національного університету харчових технологій (Украӥна)
\end{abstract}

\begin{abstract}
Анотація. У статті йде мова про вивчення та дослідження психологічних особливостей специфіки реадаптації педагогів передпенсійного віку загальноосвітніх навчальних закладів до професійного середовища, експериментально обгрунтовано психологоічні чинники, щчо впливають на реадаптацію педагогів. Обговорюються ц̆ аналізуються психологічні характеристики соціальної реадаптаџฺї особистості зрілого віку. Показано, щзо провідним соціально-психологічним чинником сочуіальної реадаптації особистості виступає ї̈ адаптаційний потенціал. Визначено рівні адаптаційного потенщіалу осіб зрілого віку в процесі соціальної реадаптації, щุо дозволяє визначити найбільш суттєву психологічну ознаку особистості зрілого віку - властивість до реадаптації. Зазначено залежність соціальнопсихологічної реадаптації від адаптаційного потенціалу.
\end{abstract}

Ключові слова: особистість, адаптація, реадаптація, соціальна реадаптаџія, передпенсійний вік, чинники реадаптації, адаптаційний потенціал, професійна діяльність, зрілий вік.

Постановка проблеми. Трансформаційні процеси сучасного суспільства зумовлюють необхідність постійних змін у психологічній адаптації особистості, що призводить до появи низки труднощів і свідчить про важливість вивчення різних аспектів проблеми реадаптації особистості.

Необхідність реадаптації особистості виникає у життєвій ситуації, що різко відрізняється від попередньої, і може бути пов'язана як із самими змінами в суспільстві, 3 появою якихось надзвичайних обставин, так і з переходом особистості від одного етапу їі розвитку й життєдіяльності до іншого. Процес реадаптації в сучасній психології розглядається двояко - або як корінна перебудова функціональних систем особистості в екстраординарних обставинах, або ж як перехід із стану адаптації в звичних умовах у стан адаптації в нових умовах, що відрізняються від попередніх умов життя й діяльності. Однак, багато вчених вважають, що цей процес пов'язаний насамперед 
iз змістовною перебудовою цінностей, цілей, норм і потребово-мотиваційної сфери особистості [3].

Актуальність вирішення проблем соціальної реадаптації особистості передпенсійного віку зумовлена численними перешкодами в процесі вторинної соціалізації, які прослідковуються змінами життєвої ситуації в осіб цього віку. Коли вплив негативних чинників перевищує наявні адаптивні можливості особистості тоді виникає необхідність у реадаптації. Тому й відбувається пошук засобів підвищення здатності особистості до адаптації в нових життєвих умовах $[1,6]$.

Аналіз підходів до проблем реадаптації людини підкреслює багатофакторність цього процесу. Реадаптацію можна визначити як кінцевий результат процесу соціальної реабілітації особистості та процес повторного включення особи в суспільний контекст і формування в неї компенсаторних соціальних навичок (після психотравм, важких і довготривалих захворювань, після примусової зміни способу життя, через які були порушені соціальні контакти тощо).

Проведений аналіз досліджень 3 проблеми соціальної реадаптації показав, що вона розглядається більшістю дослідників (О. І. Зотовою, Н. Ю. Максимовою, Л. Ф. Шестопаловою та ін.) як порушення активного пристосування індивіда до умов соціального середовища внаслідок хибного або недостатньо розвиненого уявлення людини про себе й свої соці- альні зв'язки, неадекватні засоби взаємодії, відсутність навичок спілкування тощо. Однак, недостатньо розкритою залишається проблема соціально-психологічних чинників соціальної реадаптації особистості, і насамперед, вплив на цей процес її адаптаційного потенціалу.

Розвиток особистості в зрілому віці пов'язується не просто із збереженням властивості до творчості, мотивації на рівні усвідомлення сенсів, але і неперервного їх удосконалення. Будь-яка зупинка в цій неперервності може розцінюватися деградацією та застоєм особистості. Розвиток відносин - це рух до нової якості їх здійснення. Вихід із цього стану в першу чергу обумовлюється предметною діяльністю, як внутрішньою, так і зовнішньою. Для зрілої людини «реадаптаційним» видом діяльності стає діяльність професійна.

Таким чином виникає необхідність вивчення психологічних особливостей реадаптації педагогів з метою розробки методів і способів надання психологічної допомоги даній категорії клієнтів, а загально відомий факт ускладнення адаптації з віком визначає необхідність акцентування уваги саме на такій їх віковій категорії, як передпенсійний.

Мета статті - виявити психологічні особливості реадаптації педагогів передпенсійного віку до соціальної ситуації, що змінилася.

Виклад основного матеріалу. Необхідність у соціальній реадаптації виникає в осіб передпенсійного віку, які мають знижені 
показники адаптаційного потенціалу. Тому необхідно дослідити психологічні особливості реадаптації педагогів передпенсійного віку та їх залежність від типу ставлення особистості до виходу на пенсію, самоусвідомлення, емоційної та мотиваційної сфери, від професійно важливих характеристик, загальних адаптивних здібностей.

Емпіричне дослідження проводилось у Закарпатській області, досліджувані - педагоги різних спеціальностей загальноосвітніх навчальних закладів освіти передпенсійного віку (50-55 років) та першої фази середньої дорослості (42-47 років) - по 50 осіб; працівники непедагогічного фаху передпенсійного віку (лікарі, працівники меблевої фабрики, працівники заводу, працівники пошти, працівники міліції - по 10 осіб) - 50 осіб. Вибір досліджуваних здійснювався довільно з огляду на їхній вік. Загальна кількість досліджуваних становила 150 осіб, із них - 75 жінок та 75 - чоловіків.

У дослідженні застосовувались такі психодіагностичні методики: дослідження самооцінки 3 допомогою процедури рангування (модифікація методики С. А. Будассі) [2, с. 561-563], методика «Прогноз» [2, с. 391 -394], тест на самооцінку стресостійкості особистості[13, с. 160-162], шкала реактивної тривожності Ч. Спілбергера[12, с. 61-62], методика діагностики рівня емоційного вигорання В. В. Бойка[13, с. 190-197], самооцінка емоційних станів за А. Уесманом і Д. Рігном (шкала «енергійність - втома»)[12, с. 79-81], методика діагностики рівня невротизації Л. І. Вассермана[12, с. 76-77], шкала депресії (В. Зунге, адаптація Т. І. Балашової)[12, с. 9699].

Для з'ясування специфіки реадаптації педагогів передпенсійного віку проаналізуємо результати діагностики самоусвідомлення, мотиваційної, емоційної та комунікативної сфери, сфери діяльності (що характеризують педагога як суб'єкта праці, власне його діяльність, його ставлення до діяльності, його стосунки з колегами та учнями) у фахівців даного віку. При цьому співставимо результати вивчення аналогічних характеристик у досліджуваних двох інших груп (одна 3 яких відрізняється від вище названої за критерієм віку, друга - фаху). Результати діагностики самоусвідомлення у досліджуваних усіх груп подано у таблиці 1.

Як бачимо з табл. 1, середні значення показників задоволеності собою у досліджуваних усіх груп перебувають на середньому рівні, а показники стандартного відхилення свідчать про незначну розбіжність результатів між досліджуваними в усіх групах. При цьому в досліджуваних першої групи рівень задоволеності собою дещо вищий у порівнянні 3 іншими групами.

Середні значення показників самооцінки перебувають теж на середньому рівні в усіх групах досліджуваних, показники стандартного відхилення у групах - незначні. У дос- 
ліджуваних першої групи рівень самооцінки дещо вищий, ніж в інших групах.

Середні значення показників відчуття реалізованості власного потенціалу перебувають теж на середньому рівні в усіх групах дос- ньому рівні в усіх групах досліджуваних, показники стандартного відхилення свідчать про незначну розбіжність результатів між досліджуваними в усіх групах. При цьому в досліджуваних першої групи рівень пошуку нових

Табличя 1

\section{Результати діагностики самоусвідомлення досліджуваних}

\begin{tabular}{|c|c|c|c|c|c|c|c|}
\hline \multirow[t]{2}{*}{$\begin{array}{c}\text { № } \\
\text { II/II }\end{array}$} & \multirow[t]{2}{*}{$\begin{array}{c}\text { Характеристика само- } \\
\text { усвідомлення }\end{array}$} & \multicolumn{2}{|c|}{$\begin{array}{c}\text { Педагоги передпенсій- } \\
\text { ного віку }\end{array}$} & \multicolumn{2}{|c|}{$\begin{array}{l}\text { Педагоги першої } \\
\text { фази середньої } \\
\text { дорослості }\end{array}$} & \multicolumn{2}{|c|}{$\begin{array}{l}\text { Досліджувані перед- } \\
\text { пенсійного віку не- } \\
\text { педагогіч-ного фаху }\end{array}$} \\
\hline & & $\mathrm{M}$ & $\sigma$ & $\mathrm{M}$ & $\sigma$ & $\mathrm{M}$ & $\sigma$ \\
\hline 1 & 2 & 3 & 4 & 5 & 6 & 7 & 8 \\
\hline 2 & Задоволеність собою & 6,6 & 1,97 & 6,26 & 1,97 & 6,48 & 1,9 \\
\hline 3 & Самооцінка & 0,57 & 0,16 & 0,55 & 0,16 & 0,56 & 0,17 \\
\hline 4 & $\begin{array}{l}\text { Відчуття реалізованості } \\
\text { власного потенціалу }\end{array}$ & 6,74 & 1,76 & 6,0 & 1,58 & 5,92 & 1,68 \\
\hline 5 & $\begin{array}{l}\text { Чіткість визначення сво- } \\
\text { го майбутнього }\end{array}$ & 5,7 & 1,75 & 6,94 & 1,6 & 6,38 & 1,74 \\
\hline 6 & $\begin{array}{l}\text { Пошук нових можливос- } \\
\text { тей самоздійснення у } \\
\text { професійній діяльності }\end{array}$ & 6,5 & 1,54 & 5,84 & 1,56 & 6,38 & 1,97 \\
\hline
\end{tabular}

ліджуваних, показники стандартного відхилення свідчать про незначну розбіжність результатів між досліджуваними в усіх групах. У досліджуваних першої групи рівень відчуття реалізованості власного потенціалу вищий, ніж в інших групах.

Середні значення показників чіткості визначення свого майбутнього перебувають на середньому рівні в усіх групах досліджуваних, показники стандартного відхилення у групах незначні. При цьому в досліджуваних першої групи рівень чіткості визначення свого майбутнього нижчий, ніж в інших групах.

Середні значення показників пошуку нових можливостей самоздійснення в професійній діяльності перебувають теж на серед- можливостей самоздійснення в професійній діяльності дещо вищий, ніж у досліджуваних другої і третьої групи.

Результати діагностики мотиваційної сфери в досліджуваних усіх груп подано у таблиці 2.

Як бачимо 3 табл. 2, середні значення показників наявності особистісного смислу в професійній/педагогічній діяльності в усіх групах досліджуваних середнього рівня, показники стандартного відхилення свідчать про незначну розбіжність результатів між досліджуваними в усіх групах. При цьому в досліджуваних першої групи рівень наявності особистісного смислу в професійній/педагогічній діяльності вищий, ніж у досліджуваних другої 
і третьої груп.

Середні значення показників бажання працювати в усіх групах досліджуваних середнього рівня, показники стандартного незначні. У досліджуваних першої групи рівень бажання працювати дещо нижчий, ніж у досліджуваних другої групи, і трохи вищий, ніж у досліджуваних третьої групи.

Результати діагностики емоційної сфери у досліджуваних усіх груп подано у таблиці 3.

Як бачимо 3 табл. 3, середні значення показників психічної рівноваги в усіх групах досліджуваних дещо вищі від середнього рів- тного відхилення свідчать про незначну розбіжність результатів між досліджуваними в усіх групах. При цьому в досліджуваних першої групи рівень стресостійкості дещо вищий, ніж у досліджуваних другої і третьої групи.

Середні значення показників рівня тривожності в усіх групах досліджуваних дещо вищі від середнього рівня, показники стандартного відхилення свідчать про незначну розбіжність результатів між досліджуваними в усіх групах. При цьому в досліджуваних першої групи рівень тривожності вищий, ніж у досліджуваних інших груп.

Середні значення показників синдрому

\section{Результати діагностики мотиваційної сфери досліджуваних}

\begin{tabular}{|c|l|c|c|c|c|c|c|}
\hline \multirow{2}{*}{$\begin{array}{c}\text { № } \\
\text { п/п }\end{array}$} & \multirow{2}{*}{$\begin{array}{c}\text { Характеристика мо- } \\
\text { тиваційної сфери }\end{array}$} & \multicolumn{2}{|c|}{$\begin{array}{c}\text { Педагоги передпен- } \\
\text { сійного віку }\end{array}$} & \multicolumn{2}{|c|}{$\begin{array}{c}\text { Педагоги першої } \\
\text { фази середньої } \\
\text { дорослості }\end{array}$} & \multicolumn{2}{|c|}{$\begin{array}{c}\text { Досліджувані перед- } \\
\text { пенсійного віку не- } \\
\text { педагогіч-ного фаху }\end{array}$} \\
\cline { 3 - 8 } & $\mathrm{M}$ & $\sigma$ & $\mathrm{M}$ & $\sigma$ & $\mathrm{M}$ & $\sigma$ \\
\hline 1 & 2 & 3 & 4 & 5 & 6 & 7 & 8 \\
\hline 1 & $\begin{array}{l}\text { Наявність особистіс- } \\
\text { ного смислу в профе- } \\
\text { сійній /педагогічній } \\
\text { діяльності }\end{array}$ & 6,58 & 1,58 & 5,7 & 1,57 & 5,62 & 1,71 \\
\hline 2 & Бажання працювати & 6,44 & 1,73 & 6,48 & 1,53 & 5,88 & 1,71 \\
\hline
\end{tabular}

ня, показники стандартного відхилення свідчать про незначну розбіжність результатів між досліджуваними в усіх групах. При цьому в досліджуваних першої групи рівень психічної рівноваги нижчий, ніж у досліджуваних другої та третьої груп.

Середні значення показників стресостійкості в усіх групах досліджуваних дещо вищі від середнього рівня, показники стандар- емоційного вигорання за усіма його фазами (напруження, резистенції, виснаження) в усіх групах досліджуваних низького рівня, однак показники стандартного відхилення свідчать про наявність значних розбіжностей результатів у межах кожної з груп.

Середні значення показників прояву симптомів хронічної втоми в усіх групах досліджуваних середнього рівня, показники стан- 
дартного відхилення свідчать про незначну розбіжність результатів між досліджуваними в усіх групах. При цьому в досліджуваних першої групи рівень прояву симптомів хронічної середнього рівня, показники стандартного відхилення свідчать про незначну розбіжність результатів між досліджуваними в усіх групах. При цьому в досліджуваних першої групи

Таблиия 3

\section{Результати діагностики емоційної сфери досліджуваних}

\begin{tabular}{|c|c|c|c|c|c|c|c|}
\hline \multirow{2}{*}{$\begin{array}{l}\text { № } \\
\Pi / \Pi\end{array}$} & \multirow{2}{*}{$\begin{array}{c}\text { Характеристика емо- } \\
\text { ційної сфери }\end{array}$} & \multicolumn{2}{|c|}{$\begin{array}{l}\text { Педагоги передпен- } \\
\text { сійного віку }\end{array}$} & \multicolumn{2}{|c|}{$\begin{array}{c}\text { Педагоги першої } \\
\text { фази середньої до- } \\
\text { рослості }\end{array}$} & \multicolumn{2}{|c|}{$\begin{array}{c}\text { Досліджувані передпе- } \\
\text { нсійного віку непедаго- } \\
\text { гіч-ного фаху }\end{array}$} \\
\hline & & $\bar{M}$ & $\sigma$ & $\bar{M}$ & $\sigma$ & $\bar{M}$ & $\sigma$ \\
\hline 1 & 2 & 3 & 4 & 5 & 6 & 7 & 8 \\
\hline 1 & Психічна рівновага & 5,5 & 1,56 & 5,52 & 1,64 & 5,66 & 1,64 \\
\hline 2 & Стресостійкість & 37,68 & 7,46 & 34,98 & 7,46 & 35,28 & 7,54 \\
\hline 3 & Рівень тривожності & 39,56 & 9,85 & 36,88 & 10,34 & 38,3 & 9,26 \\
\hline 4 & $\begin{array}{l}\text { Ознаки синдрому емо- } \\
\text { ційного вигорання: } \\
\text { фаза напруження } \\
\text { фаза резистенції } \\
\text { фаза виснаження }\end{array}$ & $\begin{array}{l}29,44 \\
26,06 \\
17,74 \\
\end{array}$ & $\begin{array}{c}14,68 \\
13,36 \\
7,65 \\
\end{array}$ & $\begin{array}{l}28,24 \\
25,62 \\
17,44 \\
\end{array}$ & $\begin{array}{l}14,73 \\
11,89 \\
10,14 \\
\end{array}$ & $\begin{array}{c}30,0 \\
24,28 \\
16,54 \\
\end{array}$ & $\begin{array}{c}14,07 \\
13,67 \\
7,11 \\
\end{array}$ \\
\hline 5 & $\begin{array}{l}\text { Ознаки синдрому хро- } \\
\text { нічної втоми }\end{array}$ & 4,74 & 1,66 & 5,2 & 1,65 & 5,1 & 1,91 \\
\hline 6 & $\begin{array}{l}\text { Тенденція до невроти- } \\
\text { зації }\end{array}$ & 21,44 & 9,21 & 22,02 & 6,72 & 21,74 & 8,62 \\
\hline 7 & Тенденція до депресії & 54,44 & 7,59 & 50,46 & 9,26 & 51,6 & 8,5 \\
\hline $\mathbf{8}$ & $\begin{array}{l}\text { Ставлення до місця } \\
\text { роботи /школи }\end{array}$ & 7,14 & 1,74 & 6,36 & 1,71 & 6,94 & 1,97 \\
\hline 9 & $\begin{array}{l}\text { Ставлення до колекти- } \\
\text { ву / педколективу }\end{array}$ & 7,2 & 1,84 & 6,44 & 1,91 & 6,58 & 1,92 \\
\hline 10 & $\begin{array}{l}\text { Ставлення до підлег- } \\
\text { лих / учнів }\end{array}$ & 8,96 & 11,7 & 6,44 & 1,77 & 7,18 & 2,1 \\
\hline 11 & Задоволеність працею & 6,48 & 1,61 & 5,42 & 1,34 & 6,16 & 1,83 \\
\hline 12 & $\begin{array}{l}\text { Задоволеність трудо- } \\
\text { вими досягненнями }\end{array}$ & 6,0 & 2,24 & 5,82 & 1,91 & 5,74 & 1,72 \\
\hline
\end{tabular}

втоми дещо нижчий, ніж у досліджуваних інших груп.

Середні значення показників тенденції до невротизації в усіх групах досліджуваних рівень тенденції до невротизації дещо нижчий, ніж у досліджуваних інших груп.

Середні значення показників тенденції до депресії в усіх групах досліджуваних серед- 
нього рівня, показники стандартного відхилення свідчать про незначну розбіжність результатів між досліджуваними в усіх групах. При цьому в досліджуваних першої групи рівень тенденції до депресії дещо вищий, ніж у досліджуваних інших груп.

Середні значення показників ставлення до колективу/педколективу в усіх групах досліджуваних середнього рівня, показники стандартного відхилення свідчать про незначну розбіжність результатів між досліджуваними в усіх групах. При цьому в досліджуваних першої групи ставлення до колективу/ педколективу більш позитивне в порівнянні 3 досліджуваними інших груп.

Середні значення показників ставлення до підлеглих/учнів у досліджуваних першої групи високого рівня, в інших групах - середнього, показники стандартного відхилення свідчать про незначну розбіжність результатів між досліджуваними в усіх групах.

Середні значення показників задоволеності працею в усіх групах досліджуваних середнього рівня, показники стандартного відхилення свідчать про незначну розбіжність результатів між досліджуваними в усіх групах. При цьому досліджувані першої групи більш задоволені працею в порівнянні з досліджуваними інших груп.

Середні значення показників задоволеності трудовими досягненнями в усіх групах досліджуваних середнього рівня, показники стандартного відхилення свідчать про незнач- ну розбіжність результатів між досліджуваними в усіх групах. При цьому досліджувані першої групи більш задоволені трудовими досягненнями в порівнянні 3 досліджуваними інших груп.

Результати діагностики комунікативної сфери в досліджуваних усіх груп подано у таблиці 4.

Як бачимо з табл. 4, середні значення показників наявності ознак професійної деформації в усіх групах досліджуваних середнього рівня, показники стандартного відхилення свідчать про незначну розбіжність результатів між досліджуваними в усіх групах. При цьому в досліджуваних першої групи такі показники дещо вищі.

Середні значення показників уміння уникати конфліктних ситуацій в усіх групах досліджуваних середнього рівня, показники стандартного відхилення свідчать про незначну розбіжність результатів між досліджуваними в усіх групах. При цьому в досліджуваних першої групи показники уміння уникати конфліктних ситуацій дещо вищі, ніж в інших групах.

Середні значення показників соціометричного статусу досліджуваних усіх груп середнього рівня, показники стандартного відхилення свідчать про незначну розбіжність результатів між досліджуваними в усіх групах. При цьому в досліджуваних першої групи такі показники дещо нижчі, ніж у досліджуваних другої групи та дещо вищі, ніж у третьої. 
Середні значення показників задоволеності стосунками 3 колегами досліджуваних усіх груп середнього рівня, показники стандартного відхилення свідчать про незначну розбіжність результатів між досліджуваними в усіх групах. При цьому в досліджуваних першої групи такі показники дещо нижчі, ніж у досліджуваних третьої групи та дещо вищі, ніж у другої.

Середні значення показників задоволеності стосунками 3 підлеглими/учнями досліджуваних першої групи дещо вищі середнього рівня, другої та третьої груп - середнього рівня; показники стандартного відхилення свідчать про незначну розбіжність результатів між досліджуваними в усіх групах.

Середні значення показників установок щодо підлеглих / учнів досліджуваних першої групи дещо вищі середнього рівня, другої та третьої груп - середнього рівня; показники стандартного відхилення свідчать про незначну розбіжність результатів між досліджуваними в усіх групах.

Середні значення показників установок щодо колег досліджуваних усіх груп середнього рівня, показники стандартного відхилення свідчать про незначну розбіжність результатів між досліджуваними в усіх групах. При цьому в досліджуваних першої групи такі показники дещо вищі, ніж у досліджуваних інших груп.

Результати діагностики сфери діяльності в досліджуваних усіх груп подано у таблиці 5.

Як бачимо 3 табл. 5, середні значення показників здійснення діяльності без суттєвих порушень здоров'я в усіх групах досліджуваних середнього рівня, показники стандартного відхилення свідчать про незначну розбіжність результатів між досліджуваними в усіх групах. При цьому в досліджуваних першої групи такі

Таблиия 4

\section{Результати діагностики комунікативної сфери досліджуваних}

\begin{tabular}{|c|c|c|c|c|c|c|c|}
\hline \multirow[t]{2}{*}{$\begin{array}{l}\text { № } \\
\Pi / \Pi\end{array}$} & \multirow[t]{2}{*}{$\begin{array}{c}\text { Характеристика комуніка- } \\
\text { тивної сфери }\end{array}$} & \multicolumn{2}{|c|}{$\begin{array}{c}\text { Педагоги передпенсій- } \\
\text { ного віку }\end{array}$} & \multicolumn{2}{|c|}{$\begin{array}{c}\text { Педагоги першої } \\
\text { фази середньої } \\
\text { дорослості }\end{array}$} & \multicolumn{2}{|c|}{$\begin{array}{c}\text { Досліджувані передпе- } \\
\text { нсійного віку непеда- } \\
\text { гогіч-ного фаху }\end{array}$} \\
\hline & & $\bar{M}$ & $\bar{\sigma}$ & $\bar{M}$ & $\bar{\sigma}$ & $\mathrm{M}$ & $\bar{\sigma}$ \\
\hline 1 & 2 & 3 & 4 & 5 & 6 & 7 & 8 \\
\hline 1 & $\begin{array}{l}\text { Ознаки професійної дефор- } \\
\text { мації }\end{array}$ & 5,68 & 2,02 & 5,18 & 1,88 & 5,12 & 1,83 \\
\hline 2 & $\begin{array}{l}\text { Уміння уникати конфлікт- } \\
\text { них ситуацій }\end{array}$ & 38,88 & 7,23 & 36,66 & 7,63 & 36,68 & 7,65 \\
\hline 3 & Соціометричний статус & 6,96 & 1,67 & 7,12 & 1,76 & 6,4 & 1,53 \\
\hline 4 & $\begin{array}{l}\text { Задоволеність стосунками } 3 \\
\text { колегами }\end{array}$ & 6,9 & 2,13 & 6,28 & 1,73 & 7,12 & 1,77 \\
\hline 5 & $\begin{array}{l}\text { Задоволеність стосунками } 3 \\
\text { підлеглими / учнями }\end{array}$ & 7,58 & 1,74 & 6,96 & 2 & 7 & 1,91 \\
\hline 6 & $\begin{array}{l}\text { Установки щодо підлеглих / } \\
\text { учнів }\end{array}$ & 7,54 & 1,8 & 7,3 & 1,73 & 7,14 & 1,85 \\
\hline 7 & Установки щодо колег & 7,38 & 1,93 & 6,88 & 1,75 & 7,3 & 1,81 \\
\hline
\end{tabular}


показники дещо вищі, ніж в інших групах.

Середні значення показників ефективності (оптимальної витрати сил та розподілу часу) в усіх групах досліджуваних середнього рівня, показники стандартного відхилення свідчать про незначну розбіжність результатів між досліджуваними в усіх групах. При цьому в досліджуваних першої групи такі показники дещо вищі, ніж у третій групі, і нижчі, ніж у другій.

Середні значення показників різнобічності в усіх групах досліджуваних середнього рівня, показники стандартного відхилення свідчать про незначну розбіжність результатів між досліджуваними в усіх групах. При цьому в досліджуваних першої групи такі показники нижчі, ніж в інших групах.
Середні значення показників гнучкості в усіх групах досліджуваних середнього рівня, показники стандартного відхилення свідчать про незначну розбіжність результатів між досліджуваними в усіх групах. При цьому в досліджуваних першої групи такі показники нижчі, ніж в інших групах.

Середні значення показників успішності виконання професійних завдань в усіх групах досліджуваних середнього рівня, показники стандартного відхилення свідчать про незначну розбіжність результатів між досліджуваними в усіх групах. При цьому в досліджуваних першої групи такі показники дещо вищі, ніж в інших групах.

Середні значення показників прояву творчості в здійсненні професійної діяльності

Таблиия 5

\section{Результати діагностики сфери діяльності досліджуваних}

\begin{tabular}{|c|c|c|c|c|c|c|c|}
\hline \multirow{2}{*}{$\begin{array}{c}\text { № } \\
\text { ח/п }\end{array}$} & \multirow{2}{*}{$\begin{array}{c}\text { Характеристика сфери } \\
\text { діяльності }\end{array}$} & \multicolumn{2}{|c|}{$\begin{array}{c}\text { Педагоги передпенсій- } \\
\text { ного віку }\end{array}$} & \multicolumn{2}{|c|}{$\begin{array}{c}\text { Педагоги першої } \\
\text { фази середньої доро- } \\
\text { слості }\end{array}$} & \multicolumn{2}{|c|}{$\begin{array}{c}\text { Досліджувані передпе- } \\
\text { нсійного віку непеда- } \\
\text { гогіч-ного фаху }\end{array}$} \\
\hline & & $\bar{M}$ & $\sigma$ & $\overline{\mathrm{M}}$ & $\sigma$ & $\mathrm{M}$ & $\sigma$ \\
\hline 1 & 2 & 3 & 4 & 5 & 6 & 7 & 8 \\
\hline 1 & $\begin{array}{l}\text { Здійснення діяльності без } \\
\text { суттєвих порушень здоро- } \\
\text { в'я }\end{array}$ & 7,08 & 1,81 & 6,88 & 1,96 & 7,04 & 1,88 \\
\hline 2 & $\begin{array}{l}\text { Ефективність (оптимальна } \\
\text { витрата сил та розподіл } \\
\text { часу) }\end{array}$ & 7 & 1,86 & 7,2 & 1,76 & 6,9 & 1,81 \\
\hline 3 & Різнобічність & 6,36 & 1,79 & 6,98 & 1,95 & 6,96 & 1,7 \\
\hline 4 & Гнучкість & 6,42 & 1,72 & 7,16 & 1,72 & 6,92 & 1,78 \\
\hline 5 & $\begin{array}{l}\text { Успішне виконання профе } \\
\text {-сійних завдань }\end{array}$ & 6,59 & 1,59 & 6,36 & 1,98 & 6,58 & 1,76 \\
\hline 6 & $\begin{array}{l}\text { Прояв творчості у здійс- } \\
\text { ненні професійної діяль- } \\
\text { ності }\end{array}$ & 6,66 & 1,64 & 7,16 & 1,67 & 6,12 & 1,45 \\
\hline 7 & $\begin{array}{l}\text { Уміння заповнити свій } \\
\text { вільний час }\end{array}$ & 6,58 & 1,7 & 7,14 & 1,78 & 7,2 & 1,78 \\
\hline 8 & Зростання кваліфікації & 7,12 & 1,66 & 6,84 & 1,71 & 6,78 & 1,76 \\
\hline
\end{tabular}


в усіх групах досліджуваних середнього рівня, показники стандартного відхилення свідчать про незначну розбіжність результатів між досліджуваними в усіх групах. При цьому в досліджуваних першої групи такі показники дещо вищі, ніж у третій групі, і нижчі, ніж у другій.

Середні значення показників уміння заповнити свій вільний час в усіх групах досліджуваних середнього рівня, показники стандартного відхилення свідчать про незначну розбіжність результатів між досліджуваними в усіх групах. При цьому в досліджуваних першої групи такі показники нижчі, ніж в інших групах.

Середні значення показників зростання кваліфікації в усіх групах досліджуваних середнього рівня, показники стандартного відхилення свідчать про незначну розбіжність результатів між досліджуваними в усіх групах. При цьому в досліджуваних першої групи такі показники вищі, ніж в інших групах.

Висновки. У ході емпіричного дослідження було виявлено специфіку самоусвідомлення, мотиваційної, емоційної та комунікативної сфери педагога передпенсійного віку, що характеризують його як суб'єкта праці, власне його діяльність, його ставлення до діяльності, його стосунки з колегами та учнями; а також виявлено показники реадаптації та їх залежність від типу ставлення особистості до виходу на пенсію, самоусвідомлення, емоційної та мотиваційної сфери, від професійно важливих характеристик, загальних адаптивних здібностей.

Таким чином, педагогам передпенсійного віку властиві такі ж різні рівні прояву ознак самосвідомості, діяльності, мотиваційної, емоційної та комунікативної сфер, що й більш молодшим їх колегам та ровесникам непедагогічного фаху. При цьому специфічними психологічними особливостями педагогів передпенсійного віку (що відрізняють їх, насамперед, від педагогів більш молодшого віку) виступають: відчуття більшої реалізованості власного потенціалу, менш чітке бачення власного майбутнього, схильність надавати професійній діяльності більш високого смислу.

Для оптимізації процесу реадаптації педагогів передпенсійного віку доцільно впроваджувати спеціальні методи та прийоми, що впливатимуть на розвиток психологічних характеристик-детермінант названого процесу та враховуватимуть специфічні психологічні особливості даної категорії осіб.

\section{Список використаних джерел:}

1. Боришевський M. Й. Провідні теоретикомотодологічні принципи та їх розвиток в українській психологічній науці/Проблеми заг. та пед. психол.: $3 б$. наук. Праць Ін-ту психол. ім.Г.С.Костюка АПНУ. - К., 2002. - T.IV. - Ч.5. - C.31-36.

2. Головей Л. А. Практикум по возрастной психологии: учеб. пособ. / Л. А. Головей, Е. Ф. Рыбалко. - СПб.: Речь, 2010. - 694 с.

3. Заваџька Н. Є. Психологічні основи соціальної реадаптації особистості зрілого віку: автореферат на здобуття наук.ступеня доктора психологічних наук.- К., 
$2010 \mathrm{p}$

4. Ильин Е. П. Мотивация и мотивы. - СПб.: Изд-во Питер, 2000. -512c.

5. Кокун О. М. Аналіз поняття адаптаційних можливостей людини//Проблеми заг. та пед. психол.: Зб. наук. Праць Ін-ту психол. ім.Г.С.Костюка АПНУ. - К., 2002. - T.IV. - Ч.5. - C.137-140.

6. Маркова A. К. Психология труда учителя. - М.: Логос. $-1993 .-356 \mathrm{c}$.

7. Орлов А. Б. Психология личности и сущности человека: парадигмы, проекции, практика. - М.: Логос. 1995.

8. Петряевская Л. Г. Кризисы профессионального развития учителя // Личность, семья, школа. Пособие для руководителей школ / Под ред. доктора педагогических наук С.Г.Вершловского. - СПб.: СПбГУ педагогического мастерства. - 1996. - С. 132-163.

9. Практикум по психологии профессиональной деятельности / Под ред. Г.С.Никифорова, М.А.Дмитриевой, В.М.Снеткова. -СпбГУ-2000-303 с.

10. Реан $A$. A. Психодиагностика личности в педагогическом процессе. -СПб. - 1996.

11. Рогов Е. И. Учитель как объект психологического исследования: Пособие для школьных психологов по работе с учителем и педагоги-ческим коллективом. М.: Гуманит. изд. центр.Владос. - 1998. - 496 с.

12. Самосознание проблемных подростков Н. Л. Белопольская, С. Р. Иванова, Е. В. Свистунова, Е. М. Шафирова. - М.: Институт психологии РАН, 2007. - 332 c.

13. Семиченко В. А. Психические состояния: модульный курс / В. А. Семиченко. - К.: Магистр-S, 1998. 208 c.

\section{References (Transliteration):}

1. Borishevskiy M. Y. Providni teoretiko-motodologIchnI printsipi ta iih rozvitok $\mathrm{v}$ ukraiinskIy psihologichnIy nautsi//Problemi zag. ta ped. psihol.: Zb. nauk. Prats In-tu psi- hol. Im.G.S.Kostyuka APNU. - K., 2002. - T.IV. - Ch.5. S.31-36.

2. Golovey L. A. Praktikum po vozrastnoypsihologii: ucheb. posob. / L. A. Golovey, E. F. Ryibalko. - SPb.: Rech, 2010. $-694 \mathrm{~s}$.

3. Zavatska N. E. Psihologichni osnovi sotsIalnoyi readaptatsyi osobistostI zrilogo viku: avtoreferat na zdobuttya nauk.stupenya doktora psihologichnih nauk.- K., 2010r.

4. Ilin E. P. Motivatsiya i motivyi. - SPb.: Izd-vo Piter, 2000. $-512 \mathrm{~s}$.

5. Kokun O. M. Analiz ponyattya adaptatsIynih mozhlivostey lyudini//Problemi zag. ta ped. psihol.: Zb. nauk. Prats In-tu psihol. Im.G.S.Kostyuka APNU. - K., 2002. T.IV. - Ch.5. - S.137-140.

6.Markova A.K. Psihologiya truda uchitelya. - M.: Logos. - 1993. - 356s.

7.Orlov A. B. Psihologiya lichnosti i suschnosti cheloveka: paradigmyi, proektsii, praktika. - M.: Logos. - 1995.

8. Petryaevskaya L. G. Krizisyi professionalnogo razvitiya uchitelya // Lichnost, semya, shkola. Posobie dlya rukovoditeley shkol / Pod red. doktora pedagogicheskih nauk S.G.Vershlovskogo. - SPb.: SPbGU pe-dagogicheskogo masterstva. - 1996. - S. 132-163.

9. Praktikum po psihologii professionalnoy deyatelnosti / Pod red. G.S.Nikiforova, M.A.Dmitrievoy, V.M.Snetkova. -SpbGU-2000-303 s.

10. Rean A. A. Psihodiagnostika lichnosti v pedagogicheskom protsesse. -SPb. -1996.

11. Rogov E. I. Uchitel kak ob'ekt psihologicheskogo issledovaniya: Posobie dlya shkolnyih psihologov po rabote $\mathrm{s}$ uchitelem i pedagogi $\neg$ cheskim kollektivom. - M.: Gumanit. izd. tsentr.Vlados. - 1998. - $496 \mathrm{~s}$.

12. Samosoznanie problemnyih podrostkov / N. L. Belopolskaya, S. R. Ivanova, E. V. Svistunova, E. M. Shafirova. - M.: Institut psihologii RAN, 2007. - 332 s.

13. Semichenko V. A. Psihicheskie sostoyaniya: modulnyiy kurs / V. A. Semichenko. - K.: Magistr-S, 1998. - 208 s. 


\section{Valo Larisa}

Candidate of Psychological Science, professor of psychology Svalyavsky Technical College, National University of Food Technologies (Ukraine)

\section{DIAGNOSTIC FEATURES REINTEGRATION OF TEACHERS APPROACHING RETIREMENT AGE IN TERMS OF SOCIAL AND EDUCATIONAL CHANGE}

\section{ABSTRACT}

The article deals with the study and research of psychological peculiarities of the specific rehabilitation retirement age of teachers of secondary schools to the professional environment experimentally proved psyholohoichni factors affecting the resettlement teachers. Discussed and analyzed the psychological characteristics of the individual social rehabilitation adulthood. The analysis of studies on social rehabilitation has shown that it is considered by most researchers as a violation of the individual active adaptation to the conditions of the social environment as a result of erroneous or insufficiently developed human notions about themselves and their social connections, inadequate means of interaction, lack of communication skills and more. The need for rehabilitation of personality arises in situations, which is very different from the previous one, and can be associated with both by changes in society, with the emergence of some extraordinary circumstances, and with the transition of individuals from one stage of development and of life to another. For mature man "readaptative" activity is a professional activity. The need for resettlement occurs in people close to retirement age who have reduced performance adaptive capacity. It is shown that a leading socialpsychological factor of social rehabilitation of the individual in favour of its adaptive capacity. The levels of adaptive capacity of people coming of age in the process of resettlement, to determine the most significant sign of psychological personality adulthood - property for rehabilitation. Indicated dependence of social and psychological rehabilitation of adaptive capacity. When the impact of negative factors than the existing adaptive capacity of the individual when there is a need rehabilitation. Therefore, it searches for means to improve the ability of the individual to readaptation to new living conditions.

Keywords: personality, adaptation, readaptation, social readaptation, pre-retirement age, factors rehabilitation, adaptive capacity, professional activities, mature age.

\section{Вальо Лариса Ивановна}

Кандидат психологических наук, преподаватель психологии Свалявского технического колледжа Национального университета пищевых технологий (Украина)

\section{ДИАГНОСТИКА ОСОБЕННОСТЕЙ РЕ- АДАПТАЦИИ ПЕДАГОГОВ ПРЕДПЕНСИОННОГО ВОЗРАСТА В УСЛОВИЯХ СОЦИАЛЬНО- ОБРАЗОВАТЕЛЬНЫХ ИЗМЕНЕНИЙ}

Аннотация. В статье идет речь об изучении и исследованиии психологических особенностей специфики реадаптации педагогов 
предпенсионного возраста общеобразовательных учебных заведений к профессиональной среде, экспериментально обоснованы психологические факторы, влияющие на реадаптацию педагогов. Обсуждаются и анализируются психологические характеристики социальной реадаптации личности зрелого возраста. Показано, что ведущим социальнопсихологическим фактором социальной реадаптации личности выступает ее адаптационный потенциал. Определены уровни адаптационного потенциала лиц зрелого возраста в процессе социальной реадаптации, что позволяет определить наиболее существенный психологический признак личности зрелого возраста - способность к реадаптации. Указано зависимость социальнопсихологическойреадаптации от адаптационного потенциала.

Ключевые слова: личность, адаптация, реинтеграция, социальная реинтеграция, предпенсионный возраст, факторы реадаптации, адаптационный потенциал, профессиональная деятельность, зрелый возраст. 